\title{
Effect of adding anethole to the cryopreservation medium (powdered coconut water) on morphology, kinetics, and oxidative stress of buck sperm
}

\section{Efeito da adição de anethole ao meio de criopreserção (água de coco em pó) na morfologia, cinética e estresse oxidativo do sêmen de bode}

\author{
Marcimar Silva Sousa1*; Bruna Farias Brito1; Marco Aurélio Schiavo Novaes²; \\ Talita Soares Câmara ${ }^{1}$; Ney Rômulo de Oliveira Paula3; Cristiane Clemente de \\ Mello Salgueiro;; José Ferreira Nunes ${ }^{5}$
}

\section{Highlights}

Evaluation of membrane and acrosome with flow cytometry was unaffected by anethole. Morphological damage did not affect sperm kinetics.

Higher concentrations of anethole resulted in increased damage to the middle piece.

The antioxidant did not improve sperm kinetics.

\section{Abstract}

The quality of post-thawing goat sperm is critical to the success of artificial insemination protocols and may be influenced by extenders, cryoprotectants, and antioxidant substances. Therefore, the objective of this study was to evaluate the effects of the antioxidant anethole on goat sperm diluted in preservation medium based on powdered coconut water (ACP-101C) and frozen. For that, each ejaculate was submitted to the following treatments: ACP-101c (control); control plus supplementation with 30, 300, or $2000 \mu \mathrm{g} /$ $\mathrm{mL}$ anethole. The samples were thawed and evaluated for morphology, kinetics, membrane integrity, and reactive oxygen species (ROS). The addition of anethole increased morphological abnormalities $(P<0.05)$, however, it did not affect sperm kinetics. Flow cytometry analysis showed that sperm cells cryopreserved

1 Doctor in Veterinary Science, Postgraduate Program in Veterinary Sciences, PPGCV, Universidade Estadual do Ceará, UECE, Fortaleza, CE, Brazil. E-mail: marcimarmv@hotmail.com; britobf@live.com; talitavet2003@gmail.com

2 Doctor in Animal Science, Postgraduate Program in Veterinary Sciences, PPGCV, UECE, Fortaleza, CE, Brazil. E-mail: marcoaurelioschiavo@gmail.com

${ }^{3}$ Prof., Dr., Professional Postgraduate Program in Biotechnology in Human and Animal Health, PPGBiotc, Universidade Federal do Piauí, UFPI, Teresina, PI, Brazil. E-mail: neyromulo@ufpi.edu.br

${ }^{4}$ Profa, Dra, Professional Postgraduate Program in Biotechnology in Human and Animal Health, PPGBiotc, ACP Biotecnologia. UECE, Fortaleza, CE, Brazil. E-mail: crismelloacp@gmail.com

5 Prof., Dr., Postgraduate Program in Veterinary Sciences, PPGCV, UECE, Fortaleza, CE, Brazil. E-mail: ferreira.nunes@ uece.br

* Author for correspondence

Received: Oct. 07, 2020 - Approved: July 12, 2021 
with $300 \mu \mathrm{g} / \mathrm{mL}$ anethole had lower acrosome integrity than those cryopreserved in other treatments. Evaluation of oxidative stress revealed that cells stored in the presence of $2000 \mu \mathrm{g} / \mathrm{mL}$ anethole had small amounts of ROS when compared to those preserved in the control medium alone or supplemented with $300 \mu \mathrm{g} / \mathrm{mL}$ anethole $(P<0.05)$. After cryopreservation of sperm with $2000 \mu \mathrm{g} / \mathrm{mL}$ anethole, the highest percentage of viable sperm without ROS was observed $(P<0.05)$. In conclusion, despite reducing ROS levels, the supplementation of anethole in ACP-101c did not affect sperm kinetics or membrane integrity post-thawing, however, it did cause morphological damage to sperm.

Key words: Cryopreservation. Oxidative stress. Reproduction. Semen.

\section{Resumo}

A qualidade do espermatozoide caprino pós-descongelação é crítica para o sucesso dos protocolos de inseminação artificial e pode ser influenciada por extensores, crioprotetores e substâncias antioxidantes. Portanto, o objetivo deste estudo foi avaliar os efeitos do antioxidante anetole sobre espermatozoides caprinos diluídos em meio de conservação à base de água de coco em pó (ACP-101c) e congelados. Para tanto, cada ejaculado foi submetido aos seguintes tratamentos: ACP-101c (controle); controle mais suplementação com 30, 300 ou $2000 \mu \mathrm{g} / \mathrm{mL}$ de anetole. As amostras foram descongeladas e avaliadas quanto à morfologia, cinética, integridade de membranas e espécies reativas de oxigênio. $A$ adição de anetole aumentou as anormalidades morfológicas $(P<0,05)$, no entanto, não afetou a cinética dos espermatozoides. A análise da citometria de fluxo mostrou que as células de esperma criopreservadas com $300 \mu \mathrm{g} / \mathrm{mL}$ anethole tinham integridade acrosma menor do que aquelas criopreservadas em outros tratamentos. A avaliação do estresse oxidativo revelou que as células armazenadas na presença de $2000 \mu \mathrm{g}$ / $\mathrm{mL}$ anethole apresentaram pequenas quantidades de ROS quando comparadas às preservadas em meio de controle isoladamente ou suplementadas com $300 \mu \mathrm{g} / \mathrm{mL}$ anethole $(P<0,05)$. Após a criopreservação de espermatozoides com $2000 \mu \mathrm{g} / \mathrm{mL}$ anethole, observou-se a maior porcentagem de espermatozoides viáveis sem ROS $(P<0,05)$. A população com espermatozoides viáveis sem $R O S$ foi maior quando utilizado $2.000 \mu \mathrm{g} / \mathrm{mL}(\mathrm{P}<0,05)$. Em conclusão, apesar de reduzir os níveis de ROS, a suplementação de anetole em ACP-101c não afetou a cinética espermática e a integridade da membrana pós-descongelação, entretanto, causou danos morfológicos nos espermatozoides.

Palavras-chave: Criopreservação. Estresse oxidativo. Reprodução. Sêmen.

\section{Introduction}

Several studies have been conducted aiming at improvements in post-thawing sperm quality for artificial insemination, either by testing extenders (Oliveira et al., 2011), cryoprotectants (Bispo et al., 2011; Chelucci et al., 2015), or the addition of antioxidant substances (Elsayed, El-Shamy, Abdelrazek, \& El-Badry, 2019; Memonet al., 2013; Naijian, Kohram, Shaneh, \& Sharafi, 2013).
Temperature variation in the seminal cryopreservation process can cause sperm damage, inducing osmotic stress and ice crystal formation, damage to the plasma membrane and acrosome, and and reactive oxygen species (ROS) rate deregulation (Igbokwe et al., 2019; Souza et al., 2019). However, when unbalanced, they can induce membrane, metabolic, or chromatin damage (Elsayed et al., 2019). 
Chelating metals and enzymes such as reduced glutathione (GSH), glutathione peroxidase (GSH-Px), catalase (CAT), and superoxide dismutase (SOD), present in spermatozoa and seminal fluid, act by minimizing the effects of oxidative stress (Bucak, Sariözkan, Tuncer, Uluas, \& Akçadag, 2009; Silva et al., 2011). However, their actions are often insufficient to maintain sperm quality during the freeze-thaw process (Elsayed et al., 2019). Accordingly, several substances with antioxidant action have been studied to assist in the regulation of ROS concentration in postthawing sperm (Elsayed et al., 2019; Memon et al., 2013; Silva et al., 2011).

In buck sperm, the enzyme phospholipase hydrolyzes the egg yolk lecithin widely present in the diluent, converting it to lysolecithin and fatty acids. In turn, these act directly on the sperm membrane releasing ROS (Nunes, 1982). In this case, phospholipase $A$, which is a natural antioxidant responsible for the removal of peroxyl agents, may act in a reverse way, increasing damage through the degradation of unsaturated fatty acids in the sperm membrane by lysolecithin (Aitken, Wingate, De luliis, \& McLaughlin, 2007; Nunes, 1982).

Anethole (1-methoxy-4-[(1E)-prop-1en-1-yl]benzene) is a natural anisole derivative that is abundantly present in aromatic essential oils with the Croton zehntneri plant (Polzin, Stanfill, Brown, Ashley, \& Watson, 2007). Studies with anethole have shown no genotoxicity or teratogenesis in somatic cell culture (Yea et al., 2006) and a positive effect on the elimination of ROS in vivo (Freire, Morais, Catunda, \& Pinheiro, 2005), and in vitro (Sá et al., 2017).

There are no reports on the use of anethole in the cryopreservation of sperm cells. Therefore, the present work aimed to evaluate the antioxidant effects of anethole in different concentrations in a medium based on powdered coconut water (ACP-101C) on the morphology, kinetics, and oxidative stress of cryopreserved goat sperm.

\section{Materials and Methods}

\section{Ethics approval}

The present study was carried out at the Integrated Biotechnology Center of the State University of Ceará (UECE) (latitude, $3^{\circ}$ $43^{\prime} 6^{\prime \prime} \mathrm{S}$ and longitude, $\left.38^{\circ} 32^{\prime} 36^{\prime \prime} \mathrm{W}\right)$. The present study was approved by the Ethical Committee on Animal Use at the UECE, under registration number 6305558/2014.

\section{Animals and sperm collection}

Five bucks (Capra hircus) aged between 3-5 years old were used. They were individually housed, fed with concentrate with approximately $18 \%$ crude protein, crushed Tifton hay (Cynodon sp.), goat mineral salt, and ad libitum water. Semen collections were performed every four days using the artificial vagina method. In total, nine collections were performed per animal, resulting in 45 samples.

\section{Extenders and cryopreservation}

After the analyses, the semen was diluted in a powdered coconut water-based medium (ACP-101c; 300 mOsm/L; pH 6.8; ACP Biotechnology, Fortaleza-CE, Brazil) plus 2.5\% egg yolk, $40 \mathrm{mg}$ of antibiotic (gentamicin), and $7 \%$ of glycerol (cryoprotectant), until reaching a concentration of $400 \times 106 \mathrm{sptz} / \mathrm{mL}$, as 
described in Câmara et al. (2019), which was the control treatment. The other treatments consisted of the addition of $10 \mu \mathrm{L} \mathrm{mL}^{-1}$ in three different anethole concentrations (SigmaAldrich, St Louis, USA) to the extender: 30, 300, or $2000 \mu \mathrm{g} \mathrm{mL}^{-1}$ (Sá et al., 2017).

Each ejaculate was divided into four aliquots, which were submitted to the treatments. Semen dilution was standardized to a final sperm concentration of approximately $600 \times 10^{6}$ cells $\mathrm{mL}^{-1}$. After dilution, the semen was packaged in 0.25 $\mathrm{mL}\left(150 \times 10^{6}\right.$ cells $)$ straws and sealed with polyvinyl alcohol. Semen was cryopreserved using the programmable freezer TK $3000^{\circledR}$ (TK Technology in Freezing Ltd., Uberaba, Brazil), adopting a specific refrigeration and freezing curve for buck sperm $\left(-0.25^{\circ} \mathrm{C}\right.$ min..$^{-1}$ up to $4^{\circ} \mathrm{C}$, and $-10^{\circ} \mathrm{C}$ min. ${ }^{-1}$ from $4{ }^{\circ} \mathrm{C}$ to $-120^{\circ} \mathrm{C}$ ). At -120 ${ }^{\circ} \mathrm{C}$, the straws were dipped in liquid nitrogen $\left(-196^{\circ} \mathrm{C}\right)$, stored for at least one month in a cryogenic cylinder. All extender preparation and dilution processes were performed in a 37 ${ }^{\circ} \mathrm{C}$ water bath in a partially dark room due to anethole photosensitivity.

\section{Sperm morphology}

Sperm morphological evaluation was performed as bromophenol blue-stained smears. To this end, $5 \mu \mathrm{L}$ of the sperm sample was added over $5 \mu \mathrm{L}$ of the dye on a glass slide preheated to $37^{\circ} \mathrm{C}$. The prepared slide was dried at room temperature and subsequently observed under an optical microscope (1000x). Two hundred cells per slide were quantified between normal and abnormal spermatozoa. Abnormalities were evaluated as head, middle piece, and tail changes. The morphological evaluation was performed in triplicate.

\section{Sperm kinetics}

A computerized semen analysis system was used, with the Sperm Class Analyzer ${ }^{\circledR}$ (SCA) software configured for goat sperm (head size between 10 and $70 \mu \mathrm{m}$, slow between 10 and $45 \mu \mathrm{m} \mathrm{s}^{-1}$, medium between 45 and $75 \mu \mathrm{m} \mathrm{s}^{-1}$, fast $>75 \mu \mathrm{m} \mathrm{s}^{-1}$, progressive $>80 \%$, circular $>50 \%$, and connectivity 12). The evaluations were carried out individually. For each thawed straw, a re-dilution was performed to obtain a final concentration of $25 \times 106$ cells $\mathrm{mL}^{-1}$. The sperm parameters provided by the system were: total motility (TM, $\%)$, progressive motility (PM, \%), curvilinear velocity $\left(\mathrm{VCL}, \mu \mathrm{m} \mathrm{s}^{-1}\right)$, straight line velocity $\left(\mathrm{VSL}, \mu \mathrm{m} \mathrm{s}^{-1}\right.$ ), average path velocity (VAP, $\mu \mathrm{m}$ $\mathrm{S}^{-1}$ ), linearity (LIN, \%), straightness (STR, \%), wobble (WOB, \%), amplitude of lateral head $(A L H, \mu m)$, and beat cross frequency $(B C F, H z)$. Each evaluation was performed in triplicate.

\section{Flow cytometry}

Analyses were performed on a BD FACSVerse ${ }^{\mathrm{TM}}$ flow cytometer (BD Biosciences, USA) equipped with three excitation lasers (4.2.2). For cytometer calibration, an aliquot of fresh, unlabeled semen was used to identify the spermatozoa population (Figure $1 \mathrm{~A}$ ), and another labeled with propidium iodide (Figure 1B), FITC, and DCHF-DA probes, individually and in combination. To adjust the sperm concentration for incubation and analysis, each sample was diluted to approximately $5 \mathrm{x}$ $10^{6}$ cells in PBS with $5 \%$ glycerol. Sequentially, the samples were re-diluted in PBS to a final concentration of $2.5 \times 10^{6}$ cells $\mathrm{mL}^{-1}$ and evaluated by flow cytometer (Kumaresan, Johannisson, Al-Essawe, \& Morre, 2017). After evaluation, data were analyzed using FlowJo software (FlowJo, LLC, Ashland, Ore.) to quantify different sperm populations. 


\section{Plasma membrane and acrosome integrity} analysis

Plasma membrane and sperm acrosome integrity were verified by the combination of propidium iodide probes PI (Sigma-Aldrich, St Louis, USA) and Pisum sativum agglutinin-conjugated fluorescein isothiocyanate - FITC-PSA (Sigma-Aldrich, St Louis, USA). For the evaluation, $150 \mu \mathrm{L}$ sperm aliquots were added of $3 \mu \mathrm{L} \mathrm{PI}$ and $6 \mu \mathrm{L}$ FITC into black opaque $1.5 \mathrm{~mL}$ tubes incubated at $37{ }^{\circ} \mathrm{C}$ for $10 \mathrm{~min}$. At the end of the analysis, four populations were obtained: PI+/FITC-; PI+/FITC+; PI-/FITC+; PI-/FITC- (Figure 1C).

\section{Reactive oxygen species detection}

The presence of intracellular ROS was assessed using 2',7'-dichlorofluorescein diacetate - DCHF-DA (Sigma-Aldrich, St Louis, USA) which was oxidized to green fluorescence upon penetration into the cell (Okano et al., 2019). For the evaluations, 500 $\mu \mathrm{L}$ sperm aliquots were placed in opaque black $1.5 \mathrm{~mL}$ tubes, added with $0.5 \mu \mathrm{L}$ DCHF$\mathrm{DA}$, and incubated at $37^{\circ} \mathrm{C}$ for $30 \mathrm{~min}$. Then, 3 $\mu \mathrm{L} \mathrm{PI}$ was added and incubated for $10 \mathrm{~min}$. In the end, four populations were obtained: $\mathrm{PI}^{+} /$

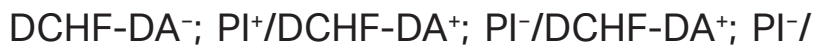
DCHF-DA- (Figure 1D).
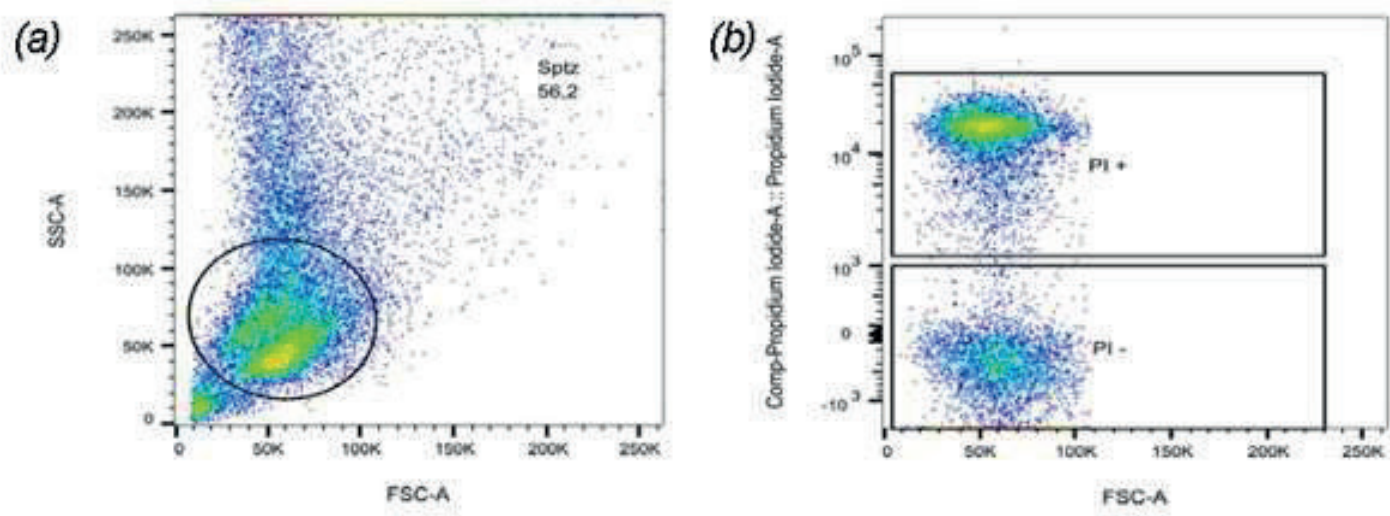

(c)

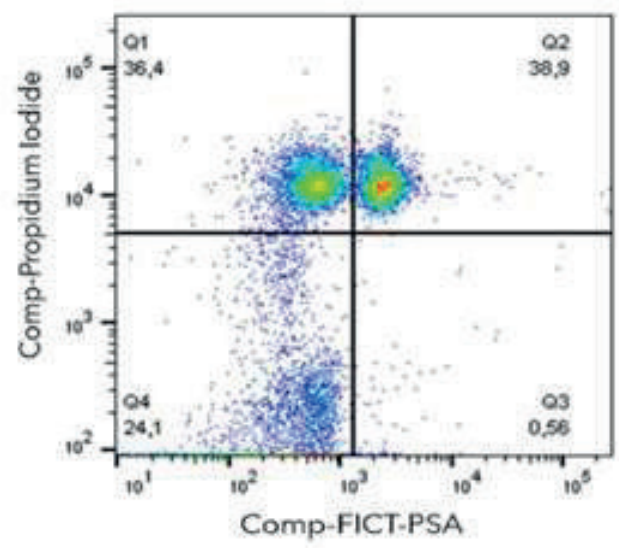

(d)

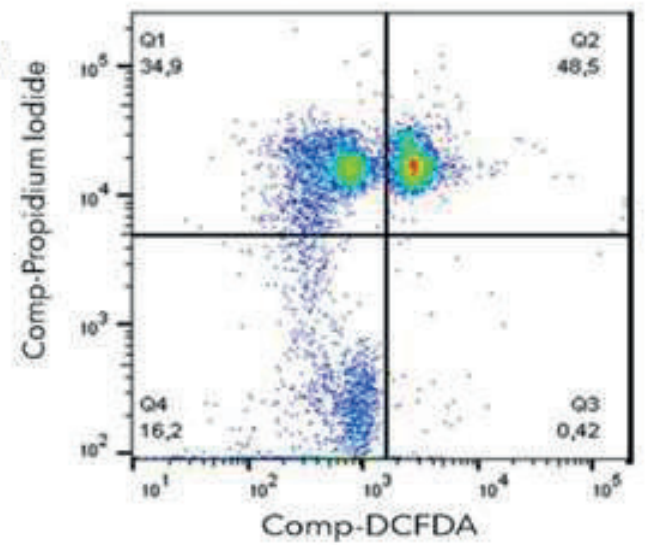

Figure 1. Representative image of spermatozoa populations by flow cytometry. (A) selection of sperm population by granulometry. (B) sperm subpopulations with intact or damaged plasmatic membrane (PI). (C) evaluation of sperm viability and acrosomal membrane integrity (PI/FITC). (D) sperm viability and hydrogen peroxide presence in the spermatozoa (PI/DCFDA). 


\section{Statistical analysis}

Data were analyzed using Sigma Plot 11 software, version 23.0 (Systat Software Inc., San Jose, CA, USA). To reduce the variability of the results, the Z-score was performed to identify outliers. The Levene test was used to verify the homogeneity of variances. For verification of normality, the Shapiro-Wilk test was adopted. For comparison between treatments, ANOVA was performed, followed by Fisher's test (DMS). Data were presented as mean ( \pm SEM), and statistical significance was set at $P<0.05$.

\section{Results and Discussion}

\section{Morphological damage}

The powdered coconut water-based medium (ACP-101c; control) was effective in protecting the sperm morphology during the freeze-thaw process, maintaining a percentage of normal cells above $75 \%$ (Table 1). The addition of anethole at any concentration (30, 300 , and $2000 \mathrm{\mu g} \mathrm{mL}^{-1}$ ) reduced the percentage of normal spermatozoa $(P<0.05)$. The results indicate that the addition of anethole to the seminal extender, at all concentrations, significantly increased sperm tail damage $(P<$ 0.05). However, only the addition of $30 \mu \mathrm{g} \mathrm{mL}^{-1}$ to ACP-101c did not cause significant damage in the middle piece compared to the control $(P>0.05)$. When comparing treatments with anethole, the addition of $30 \mu \mathrm{g} \mathrm{mL}$ showed less damage to the intermediate part when compared to treatment with $2000 \mu \mathrm{gL}(\mathrm{P}<$ 0.05).

\section{Table 1}

Mean and error of the mean of sperm morphology of different anethole concentrations added to ACP101c diluent

\begin{tabular}{|c|c|c|c|c|c|}
\hline \multirow{2}{*}{ Parameters } & \multirow{2}{*}{$\mathrm{N}$} & \multirow{2}{*}{$\begin{array}{c}\text { ACP-101c } \\
\text { (control) }\end{array}$} & \multicolumn{3}{|c|}{ Anethole } \\
\hline & & & $30 \mu \mathrm{g} \mathrm{mL}^{-1}$ & $300 \mu \mathrm{g} \mathrm{mL}^{-1}$ & $2000 \mu \mathrm{g} \mathrm{mL}^{-1}$ \\
\hline Normal spermatozoa & 45 & $77.8+1.05^{a}$ & $70.7+1.16^{b}$ & $67.4+1.15^{b}$ & $67.4+1.32^{b}$ \\
\hline Head defect & 45 & $1.31+0.13^{a}$ & $1.64+0.13^{a}$ & $1.84+0.14^{a}$ & $1.98+0.17^{a}$ \\
\hline Middle piece defect & 45 & $10.1+0.68^{a}$ & $13.0+0.78^{a b}$ & $15.7+0.87^{b c}$ & $16.1+0.90^{c}$ \\
\hline Tail defect & 45 & $9.61+0.48^{a}$ & $13.4+0.64^{b}$ & $13.9+0.59^{b}$ & $13.2+0.61^{b}$ \\
\hline
\end{tabular}

*Different superscript lowercase letters on the same line $(\mathrm{P}<0.05)$. Data presented as mean + standard error. ACP-101c = extender medium based on powdered coconut water.

\section{Evaluation of sperm kinetics}

The total and progressive motility; the curvilinear, straight line and average path velocities; the linearity, straightness, wobble, amplitude of lateral head, and beat cross frequency were verified using the CASA system (Table 2). The addition of anethole to ACP-101C did not jeopardize the kinetics of post-thawed spermatozoa $(P>0.05)$. 


\section{Table 2}

Mean and error of the mean of kinetic parameters of spermatozoa of different anethole concentrations added to ACP-101c diluent

\begin{tabular}{|c|c|c|c|c|c|}
\hline \multirow{2}{*}{ Parameters } & \multirow{2}{*}{$\mathrm{N}$} & \multirow{2}{*}{$\begin{array}{c}\text { ACP-101c } \\
\text { (control) }\end{array}$} & \multicolumn{3}{|c|}{ Anethole } \\
\hline & & & $30 \mu \mathrm{g} \mathrm{mL}^{-1}$ & $300 \mu \mathrm{g} \mathrm{mL}^{-1}$ & $2000 \mu \mathrm{g} \mathrm{mL}^{-1}$ \\
\hline TM (\%) & 45 & $33.4+2.09$ & $30.7+2.58$ & $31.9+2.31$ & $33.0+2.42$ \\
\hline PM (\%) & 45 & $17.7+1.48$ & $15.5+1.64$ & $15.7+1.60$ & $15.9+1.62$ \\
\hline $\operatorname{VCL}\left(\mu \mathrm{m} \mathrm{s}^{-1}\right)$ & 45 & $67.5+1.98$ & $65.3+1.88$ & $65.8+2.17$ & $64.4+2.04$ \\
\hline $\operatorname{VSL}\left(\mu \mathrm{m} \mathrm{s}^{-1}\right)$ & 45 & $50.4+2.11$ & $47.6+1.74$ & $48.8+2.17$ & $47.0+1.88$ \\
\hline $\operatorname{VAP}\left(\mu \mathrm{m} \mathrm{s}^{-1}\right)$ & 45 & $50.9+2.13$ & $56.7+1.88$ & $50.7+2.19$ & $55.6+2.01$ \\
\hline LIN (\%) & 45 & $73.8+1.09$ & $71.6+0.93$ & $72.4+1.02$ & $72.2+1.02$ \\
\hline STR (\%) & 45 & $84.5+0.64$ & $83.2+0.62$ & $83.1+0.64$ & $83.8+0.60$ \\
\hline WOB (\%) & 45 & $86.4+0.76$ & $85.8+0.66$ & $86.5+0.62$ & $85.9+0.70$ \\
\hline $\mathrm{ALH}(\mu \mathrm{m})$ & 45 & $2.07+0.39$ & $2.06+0.43$ & $2.05+0.33$ & $2.06+0.49$ \\
\hline $\mathrm{BCF}(\mathrm{Hz})$ & 45 & $8.10+0.14$ & $7.85+0.14$ & $7.98+0.88$ & $8.09+0.11$ \\
\hline
\end{tabular}

${ }^{*} \mathrm{P}>0.05$. Data presented as mean + standard error. ACP-101c $=$ extender medium based on powdered coconut water; $\mathrm{TM}=$ total motility; $\mathrm{PM}=$ progressive motility $\mathrm{VCL}=$ curvilinear velocity $; \mathrm{VSL}=$ straight line velocity; $\mathrm{VAP}$ = average path velocity; $\mathrm{LIN}=$ linearity; $\mathrm{STR}=$ straightness; $\mathrm{WOB}=$ wobble; $\mathrm{ALH}=$ amplitude of lateral head; $\mathrm{BCF}=$ beat cross frequency.

\section{Sperm membrane and acrosome integrity}

The addition of anethole to ACP-101c did not improve sperm membrane integrity at any of the concentrations studied $(P>$ 0.05) (Table 3). The same occurred when the membrane integrity and acrosome parameters were evaluated together $(P>0.05)$. However, the percentage of spermatozoa that presented intact acrosome in the treatment with the addition of $2000 \mu \mathrm{g} \mathrm{mL}^{-1}$ of anethole to ACP$101 \mathrm{c}(53.2 \pm 3.1 \%)$ was higher than the $300 \mu \mathrm{g}$ $\mathrm{mL}^{-1}(43.1 \pm 3,7 \% ; \mathrm{P}<0.05)$, and similar to the control and treatment with the addition of 30 $\mu \mathrm{g} \mathrm{mL} \mathrm{L}^{-1}$ of anethole to ACP-101c (P > 0.05).

\section{Table 3}

Mean and error of the mean of spermatic membrane and acrosomal integrity parameters and low levels of reactive oxygen species of different anethole concentrations added to ACP-101c diluent

\begin{tabular}{ccccc|} 
Parameters & ACP-101c & \multicolumn{3}{c|}{ Anethole } \\
\cline { 5 - 5 } & (control) & $30 \mu \mathrm{mL}^{-1}$ & $300 \mu \mathrm{mL}^{-1}$ & $2000 \mu \mathrm{g} \mathrm{mL}^{-1}$ \\
Intact membrane (\%) & $24.4 \pm 1.7$ & $25.1 \pm 2.1$ & $25.0 \pm 1.7$ & $28.1 \pm 1.6$ \\
Intact acrosome (\%) & $48.1 \pm 3.0^{\mathrm{ab}}$ & $47.0 \pm 3.3^{\mathrm{ab}}$ & $43.1 \pm 3.7^{\mathrm{b}}$ & $53.2 \pm 3.1^{\mathrm{a}}$ \\
Intact membrane and acrosome (\%) & $24.3 \pm 2.5$ & $28.7 \pm 1.9$ & $24.4 \pm 3.7$ & $25.8 \pm 3.0$ \\
ROS low concentration (\%) & $30.9 \pm 10.2^{\mathrm{bc}}$ & $60.4 \pm 12.6^{\mathrm{ab}}$ & $29.2 \pm 8.9^{\mathrm{c}}$ & $64.9 \pm 11.8^{\mathrm{a}}$ \\
Intact membrane/ROS low concentration (\%) & $7.3 \pm 2.8^{\mathrm{b}}$ & $16.3 \pm 3.9^{\mathrm{a}}$ & $7.82 \pm 3.5^{\mathrm{b}}$ & $16.80 \pm 3.8^{\mathrm{a}}$
\end{tabular}

*Different superscript lowercase letters on the same line $(P<0.05)$. ACP-101c $=$ extender medium based on powdered coconut water. ROS = reactive oxygen species. 


\section{ROS concentration}

Table 3 shows the percentage of sperm with or without ROS. When DCHF-DA negative sperm populations were compared, for low or no ROS concentrations, it was found that the $2000 \mu \mathrm{L}$ treatment (64.9\%) was superior $(\mathrm{P}<$ $0.05)$ to the control (30.9\%) and the $300 \mu \mathrm{L}$ $(29.2 \%)$ treatment, but did not differ $(P>0.05)$ from the $30 \mu \mathrm{L}(60.4 \%)$ treatment. However the control did not differ from the $30 \mu \mathrm{L}$ and $300 \mu \mathrm{L}$ treatments $(\mathrm{P}>0.05)$. Regarding sperm populations with intact membranes and low ROS concentrations, the $2000 \mu \mathrm{L}$ (16.8\%) and $30 \mu \mathrm{L}(16.3 \%)$ treatments were superior $(\mathrm{P}<0.05)$ to the control $(7.30 \%)$ and $300 \mu \mathrm{L}$ (7.82\%) treatments.

The addition of anethole to the cryopreservation diluent did not affect the percentage of mobile and progressive sperm and did not influence sperm motility. Comparatively, the eugenol addition to bovine seminal extended, another short-chain phenolic compound, demonstrated efficiency in sperm motility parameters at concentrations of 10 and $50 \mu \mathrm{M}$ (Castelo Branco et al., 2020). It is noteworthy that the results obtained in this study regarding anethole were compared to the control (diluent ACP-101c) and showed good kinetic results for goat spermatozoa, as described by Câmara et al. (2019). In addition, the results of the present study show that anethole is beneficial to the maintenance integrity of the acrosome membrane at concentrations of 30 and $2,000 \mu \mathrm{L}$. Other results presented demonstrate that anethole $(0.1 \mu \mathrm{M}, 1 \mu \mathrm{M}, 10 \mu \mathrm{M}$, and $100 \mu \mathrm{M})$ did not show deleterious effects on sperm viability or integrity of the human sperm acrosome (Luo et al., 2020).
Regarding morphology, the proportions found in this study show that anethole increased the percentage of sperm abnormalities, especially tail changes. In the qualitative evaluation of morphology, the tail reflex or strongly folded tail were the most common alterations found in samples treated with anethole. The reflex was observed in the transition from the intermediate piece to the flagellum. This phenomenon can be explained by the flagellum structures' disposition, where small damage to the mitochondrial network can lead to an asymmetry in energy conduction causing morphological changes in the region of the middle piece and flagellum (Gu, Zhao, Wang, \& Sun, 2019). Another mechanism indicates that anethole, in high concentrations (10 and $100 \mu \mathrm{M}$ ), reduced basal tyrosine phosphorylation and increased progesterone, [Ca2+] ion, and CatSper current, a predominant cationic sperm channel for the influx of $\mathrm{Ca} 2+$. This mechanism occurred mainly in the middle piece due to the presence of mitochondria in the region (Luo et al., 2020).

When analyzing the results of oxidative stress, it was observed that concentrations of 30 and $2000 \mu \mathrm{g} / \mathrm{mL}$ of anethole in the seminal extender reduced the rates of ROS production. This can be explained by the inhibition of ROS generation and its consequent degradation into hydroxyl radical $(\mathrm{OH}-)$, since anethole has an affinity for the incorporation of hydroxyl groups in the double bond of the molecules' side chain, increasing the antioxidant capacity of the diluent (Freire et al., 2005). The treatment with $300 \mu \mathrm{g} / \mathrm{mL}$ showed inferior results, it is not possible to detail the mechanism of this result with only the tests performed in this experiment, however, this concentration proved to be prejudicial, as 
suggested by Majzoub and Agarwal (2018). In these cases, the treatment with $30 \mu \mathrm{g} / \mathrm{mL}$ had an action dose, in which there was a reduction in intracellular $\mathrm{OH}^{-}$by inducing the intracellular activity of SOD and CAT (Choi \& Hwang, 2004).

This result indicate the anethole it seems to be a primary antioxidant, with a higher efficiency action on free radicals than on $\mathrm{H}_{2} \mathrm{O}_{2^{\prime}}$ which is not a primary oxidative agent (Chainy, Manna, Chaturvedi, \& Aggarwal, 2000). In cell incubation with $1 \mathrm{mM}$ anethole, the intracellular efflux of glutathione (GSH) and glutathione-Stransferase (GST) demonstrated an efficient intracellular antioxidant action in reducing the levels of primary radicals such as hydroxyl (Dringen, Hamprecht, \& Drukarch, 1998; Drukarch, Schepens, Stoof, \& Langeveld, 1997). The same was verified in this study when the DCHF-DA probe was used in the $2000 \mu \mathrm{g} / \mathrm{mL}$ treatment. By reducing the concentration of ROS, anethole demonstrated a potent antioxidant action as pointed out by Oktay, Gülcin and Küfrevioglu (2003), when they used fennel extract (Foeniculum vulgare), of which the main component is anethole.

\section{Conclusion}

In general, despite reducing ROS levels, the supplementation of anethole in ACP-101c did not affect sperm kinetics and membrane integrity post-thawing, however, it caused morphological damage in sperm. Thus, it is not recommended for buck sperm.

\section{Acknowledgments}

The authors acknowledge the support of the Postgraduate Program in Veterinary Sciences of the Ceará State University, the
National Council of Science and Technology (CNPq) for project funding and research grant, Cryogenics Laboratory of the Physics Department, and the Multiples Unit of the Research and Development Center of Medicines of the Federal University of Ceará for the technical support.

\section{Funding information}

This work was supported by the CNPq: PhD scholarship, under Grant Number:140195/2017-3; Support Program for Centers of Excellence - PRONEX/Award Number: PR2-0101-00049.01.00/15.

\section{References}

Aitken, R. J., Wingate, J. K., De luliis, G. N., \& McLaughlin, E. A. (2007). Analysis of lipid peroxidation in human spermatozoa using BODIPY C11. Molecular Human Reproduction, 13(4), 203-211. doi: 10.10 93/molehr/gal119

Bispo, C. A. S., Pugliesi, G., Galvão, P., Rodrigues, M. T., Ker, P. G., Filgueiras, B., \& Carvalho, G. R. (2011). Effect of low and high egg yolk concentrations in the semen extender for goat semen cryopreservation. Small Ruminant Research, 100(1), 54-58. doi: 10.1016/j.smallrumres.2011.05.003

Bucak, M. N., Sariözkan, S., Tuncer, P. B., Ulutaş, P. A., \& Akçadağ, H. I. (2009). Effect of antioxidants on microscopic semen parameters, lipid peroxidation and antioxidant activities in Angora goat semen following cryopreservation. Small Ruminant Research, 81(2-3), 90-95. doi: 10.1016/jsmallrumres.20 08.11.011 
Câmara, T. S., Sousa, A., Jr., Barçante, F. P. S., Silva, J. H. L., Sousa, M. S., Machado, A. A. C.,... Nunes, J. F. (2019). Comparação da qualidade seminal de caprinos das raças Canindé e Alpina Britânica no Nordeste brasileiro. Arquivo Brasileiro de Medicina Veterinária e Zootecnia, 71(04), 12601268. doi: 10.1590/1678-4162-10297

Castelo Branco, Y. N. T. C., Castelo Branco, M. A., Lustosa, M. S. C., Nascimento, I. M. R., Barros, F. N., Sousa, M. A. C., Fo,... Souza, J. A. T. (2020). The use of Eugenol in the cryopreservation of bovine sêmen. Brazilian Journal of Development, 6(11), 86336-86355. doi: 10.34117/bjdv6n11 $-162$

Chainy, G. B. N., Manna, S. K., Chaturvedi, M. M., \& Aggarwal, B. B. (2000). Anethole blocks both early and late cellular responses transduced by tumor necrosis factor: Effect on NF-kB, AP-1, JNK, MAPKK and apoptosis. Oncogene, 19(25), 2943-2950. doi: 10.1038/sj.onc. 1203614

Chelucci, S., Pasciu, V., Succu, S., Addis, D., Leoni, G. G., Manca, M. E., \& Berlinguer, F. (2015). Soybean lecithin-based extender preserves spermatozoa membrane integrity and fertilizing potential during goat semen cryopreservation. Theriogenology, 83(6), 1064-1074. doi: 10.1016/j.theriogenology.2014.12.012

Choi, E., \& Hwang, J. (2004) Antiinflammatory, analgesic and antioxidant activities of the fruit of Foeniculum vulgare. Fitoterapia, 75(6), 557-565. doi: 10.1016/j. fitote.2004.05.005

Dringen, R., Hamprecht, B., \& Drukarch, B. (1998). Anethole dithiolethione, a putative neuroprotectant, increases intracellular and extracellular glutathione levels during starvation of cultured astroglial cells. Naunyn-Schmiedeberg's Arch Pharmacol, 358(6), 616-622. doi: 10.1007/ pl00005302

Drukarch, B., Schepens, E., Stoof, J. C., \& Langeveld, C. H. (1997). Anethole dithiolethione prevents oxidative damage in glutathione-depleted astrocytes. European Journal of Pharmacology, 329(2-3), 259-262. doi: 10.1016/S00142999(97)89187-X

Elsayed, D. H., El-Shamy, A. A., Abdelrazek, H. M. A., \& El-Badry, D. A. (2019). Effect of genistein on semen quality, antioxidant capacity, caspase-3 expression and DNA integrity in cryopreserved ram spermmatozoa. Small Ruminant Research, 177(1), 50-55. doi: 10.1016/j. smallrumres.2019.06.009

Freire, R. S., Morais, S. M., Catunda, F. E. A., \& Pinheiro, D. C. S. N. (2005). Synthesis and antioxidant, anti-inflammatory and gastroprotector activities of anethole and related compounds. Bioorganic \& Medicinal Chemistry, 13(13), 4353-4358. doi: 10.1016/j.bmc.2005.03.058

Gu, N.-H., Zhao, W.-L., Wang, G.-S., \& Sun, F. (2019). Comparative analysis of mammalian sperm ultrastructure reveals relationships between sperm morphology, mitochondrial functions and motility. Reproductive Biology and Endocrinology, 17(1), 66. doi: 10.1186/ s12958-019-0510-y

Igbokwe, A. A., lyasere, O. S., Sobayo, R. A., lyasere, S., Animashaun, R. I., Balogun, F. A.,... Daramola, J. O. (2019). Comparative effect of slow and rapid freezing on sperm functional attributes and oxidative stress parameters of goat spermatozoa 
cryopreserved with tiger nutmilkextender. Reproduction in Domestic Animals, 54(3), 551-559. doi: 10.1111/rda.13393

Kumaresan, A., Johannisson, A., Al-Essawe, E. M., \& Morrell, J. M. (2017). Sperm viability, reactive oxygen species, and DNA fragmentation index combined can discriminate between above- and belowaverage fertility bulls. Journal of Dairy Science, 100(7), 5824-5836. doi: 10.3168/ jds.2016-12484

Luo, T., Wang, F., Weng, S., Chen, H., Kang, H., Wang, J., \& Luo, S. (2020) Anethole compromises human sperm function by affecting the sperm intracellular calcium concentration and tyrosine phosphorylation. Reproductive Toxicology, 93(1), 99-105. doi: 10.1016/j. reprotox.2020.01.007

Majzoub, A., \& Agarwal, A. (2018). Systematic review of antioxidant types and doses in male infertility: benefits on semen parameters, advanced sperm function, assisted reproduction and live-birth rate. Arab Journal of Urology, 16(1), 113-124. doi: 10.1016/j.aju.2017.11.013

Memon, A. A., Wahid, H., Rosnina, Y., Goh, Y. M., Ebrahimi, M., \& Nadia, F. M. (2013). Effect of ascorbic acid concentrations, methods of cooling and freezing on boer goat semen cryopreservation. Reproduction in Domestic Animals, 48(2), 325-330. doi: 10.1111/j.1439-0531.2012.02155.x

Naijian, H. R., Kohram, H., Shahneh, A. Z., \& Sharafi, M. (2013). Effects of various concentrations of BSA on microscopic and oxidative parameters of Mahabadi goat semen following the freeze-thaw process. Small Ruminant Research,
113(2-3), 371-375. doi: 10.1016/j.small rumres.2013.03.015

Nunes, J. F. (1982). Étude des effets du plasma seminal sur la survie in vitro des espermatozöides de bouc. Thèse de doctorat, Paris VI, Paris, França.

Okano, D. S., Penitente, J. M., F., Gomez León, V. E., Maitan, P. P., Silveira, C. O., Waddington, B.,... Guimarães, J. D. (2019). In vitro evaluation of cryopreserved bovine sperm and its relation to field fertility in fixed-time artificial insemination. Reproduction in Domestic Animals, 54(3), 604-612. doi: 10.1111/rda.13401

Oktay, M., Gulcin, I., \& Kufrevioglu, O. (2003). Determination of in vitro antioxidant activity of fennel (Foenicu-lum vulgare) seed extracts. LWT - Food Science and Technology, 36(2), 263-271. doi: 10.1016/ S0023-6438(02)00226-8

Oliveira, R. V., Nunes, J. F., Salgueiro, C. C. M., Cavalcante, J. M. M., Brasil, O. O., \& Moura, A. A. A. N. (2011). Avaliação de espermatozoides caprinos congelados em meio à base de água de coco em pó (ACP-101 ${ }^{\circledR}$ ) ou TRIS. Arquivo Brasileiro de Medicina Veterinária e Zootecnia, 63(6), 1295-1302. doi: 10.1590/S0102-093520 11000600003

Polzin, G. M., Stanfill, S. B., Brown, C. R., Ashley, D. L., \& Watson, C. H. (2007). Determination of eugenol, anethole, and coumarin in the mainstream cigarette smoke of Indonesian clove cigarettes. Food and Chemical Toxicology, 45(10), 1948-1953. doi: 10.1016/j.fct.2007.04.012

Sá, N. A. R., Araújo, V. R., Correia, H. H. V., Ferreira, A. C. A., Guerreiro, D. D., Sampaio, A. M.,... Figueiredo, J. R. (2017). Anethole 
improves the in vitro development of isolated caprine secondary follicles. Theriogenology, 89(1), 226-234. doi: 10. 1016/j.theriogenology.2015.12.014

Silva, S. V., Soares, A. T., Batista, A. M., Almeida, F. C., Nunes, J. F., Peixoto, C. A., \& Guerra, M. M. P. (2011). In vitro and in vivo evaluation of ram sperm frozen in tris egg-yolk and supplemented with superoxide dismutase and reduced glutathione. Reproduction, Fertility and Development, 46(5), 874-881. doi: 10.1111/j.1439-0531.2011.01758.x
Souza, C., Brandão, F., Santos, J., Alfradique, V., Brair, V., Prellwitz, L.,... Souza-Fabjan, J. M. (2019) 38 Ram sperm longevity after cryopreservation in extender containing L-carnitine. Reproduction, Fertility and Development, 32(2), 145-145. doi: 10.10 71/RDv32n2Ab38

Yea, S. S., Jeong, H. S., Choi, C. Y., Park, K. R., Oh, S., Shin, J. G., \& Yun, C. H. (2006). Inhibitory effect of anethole on T-lymphocyte proliferation and interleukin-2 production through down-regulation of the NF-AT and AP-1. Toxicology in Vitro, 20(7), 10981105. doi: 10.1016/j.tiv.2006.01.020 